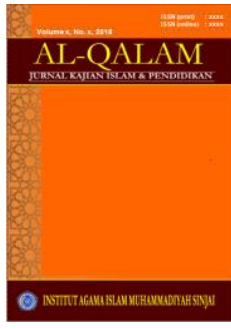

\title{
HERIDITAS DAN LINGKUNGAN PENDIDIKAN ISLAM
}

\author{
Oleh : Safaruddin
}

$* * *$

\begin{abstract}
Abstrak
Heriditas adalah istilah yang dipakai untuk menyebut semua potensi yang dibawa sejak lahir dan memiliki kemungkinan untuk muncul pada perkembangan manusia. Istilah ini mencakup pengertian bakat dan keturunan. Adapun lingkungan adalah sesuatu yang mempengaruhi perkembangan diri manusia Mengenai implikasi heriditas dan lingkungan dalam perkembangan diri manusia telah muncul berbagai pandangan yang beragam yaitu aliran empirisme, nativisme, naturalisme, konvergensi serta diindonesia diwakili oleh tut wuri hanadayani merupakan aliran yang memadukan antara empirisme dengan nativisme. Dalam memahami masalah kekuasaan Tuhan ada dua golongan secara garis besar yaitu Pertama golongan mu'tazilah dan qadariyah. kedua yaitu golongan asy'ariyah dan jabariah.
\end{abstract}

Kata Kunci : Hereditas, lingkungkungan dan pendidikan Islam

\section{PENDAHULUAN}

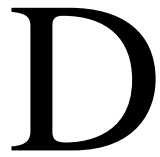
alam perkembangan ilmu pendidikan telah muncul berbagai pandangan mengenai soal heriditas atau pembawaan pada manusia, pada awalnya berpandangan bahwa perkembangan manusia mutlak ditentukan oleh lingkungan termasuk pendidikan. Setelah itu muncul reaksi bahwa setiap individu yang lahir ke dunia ini pasti dengan satu pembawaan tertentu. Ini berarti bahwa karakteristik setiap individu berbeda dan diperoleh dari pewarisan atau pemindahan cairan "germinal" dari pihak orangtuanya. Di samping itu, individu tumbuh dan berkembang tidak terlepas dari lingkungan baik lingkungan fisik

${ }^{1}$ Dosen STAI Muhammadiyah Sinjai 
maupun lingkungan sosial. Setiap pertumbuhan dan perkembangan yang kompleks merupakan hasil interaksi dari hereditas dan lingkungan. Agar kita dapat mengerti dan mengontrol perkembangan individu baik dari tingkah lakunya, kita hendaknya mengetahui peranan masing-masing (pembawaan dan lingkungan).

\section{PEMBAHASAN}

\section{A. Pengertian Heriditas dan Lingkungan}

\section{Heriditas}

Heriditas adalah suatu konsep yang dipercayai atau dikemukakan oleh orang-orang yang mempercayai adanya potensi dasar manusia yang akan berkembang sendiri atau berkembang dengan berinteraksi dengan lingkungan. Adapulah istilah lain yang bisaa diidentikkan dengan pembawaan atau heriditas yakni istilah keturunan dan bakat. Sebenarnya ketiga istilah tersebut tidaklah sama persis pengertiannya.

Menurut Ngalim Purwanto bahwa Heriditas adalah seluruh kemungkinan atau kesanggupan (potensi) yang terdapat pada suatu individu dan yang selama masa perkembangan benar-benar dapat diwujudkan. $^{2}$

Pembawaan tersebut berupa ciri, sifat dan kesanggupan yang bisaa bersifat fisik atau bisa juga yang bersifat psikis (kejiwaan). Warna ramut bentuk mata dan kemampuan berjalan adalah contoh ciri dan kesanggupan yang bersifat fisik sedangkan sifat malas, lekas marah dan kemampuan memahami sesuatu dengan cepat adalah sifat-sifat psikis yang mungkin berasal dari heriditas atau pembawaan. Pembawaan yang bermacammacam itu tidak berdiri sendiri, yang satu lepas dari yang lain. Seluruh pembawaan yang terdapat dalam seseorang merupakan keseluruhan yang erat dengan hubungannya satu sama lain ; yang satu menentukan, mempengaruhi, menguatkan atau melemahkan yang lain. Manusia tidak dilahirkan dengan membawa sifat-sifat pembawaan yang masing-masing berdiri sendiri, tetapi merupakan struktur pembawaan. Pembawaan itu menentukan apakah yang mungkin terjadi pada seseorang. ${ }^{3}$

\section{Lingkungan}

${ }^{2}$ M. Ngalim Purwanto. Ilmu Pendidikan Teoritis dan Praktis (Cet. VII Bandung : Remaja Rosda karya. 1994) hal. 53

${ }^{3}$ Ibid hal,. 54 
Dalam kamus besar bahasa Indonesia disebutkan bahwa kata lingkungan berarti "semua yang mempengaruhi pertumbuhan manusia dan hewan. ${ }^{4}$

Dalam konteks pendidikan, objek pengaruh tertentu saja dibatasa hanya pada pertumbuhan manusia, tidak mencakup pertumbuhan hewan. Oleh karena itu M. Ngalim Purwanto menyatakan bahwa yang dimaksud dengan lingkungan didalam pendidikan ialah setiap pengaruh yang terpancar dari orang lain, binatang, alam kebudayaan, adat-istiadat iklim dan lain-lain terhadap diri manusia yang sedang berkembang. ${ }^{5}$

Menurut penulis mungkin yang dimaksud oleh Ngalim diatas adalah pengaruh lingkungan (bukan lingkungan). Dengan asumsi ini maka, lingkungan adalah segala sesuatu yang mempengaruhi perkembangan diri manusia yakni orang lain (individu atau masyarakat), binatang alam, kebudayaan, adat-istiadat iklim dan lain-lain.

Sartain $^{6}$ seorang ahli psikologi Amerika membagi lingkungan menjadi tiga bagian yaitu :

a. Lingkungan alam atau luar (eksternal of physical environment) ialah segala sesuatu yang ada di dunia ini selain manusia

b. Lingkungan dalam (internal environment) ialah segala sesuatu yang telah masuk kedalam diri kita, yang dapat mempengaruhi pertumbuhan fisik kita, misalnya makanan yang telah diserap oleh pembuluh darah kita

c. Lingkungan sosialialah semua orang atau manusia lain yang mempengaruhi kita

Mengenai jenis lingkungan yang ketiga, Ralph Liton seorang antropolog Amerika, mengistilahkannya sebagai lingkungan manusiawi. Menurutnya lingkungan manusiawi itu mencakup masyarakat dan cara hidup yang khas dari masyarakat, yaitu kebudayaan. Baik Sartain maupun Linton sepakat bahwa lingkungan sosial atau lingkungan manusiawi adalah yang paling besar berpengaruh dalam perkembangan pribadi seseorang.

\section{B. Teori Mengenai Heriditas dan Lingkungan}

${ }^{4}$ Tim Penyusun kamus pusat pembinaan dan pengembangan bahasa, (cet. II Jakarta : Balai Pustaka, 1989) hal. 526

${ }^{5}$ M. Ngalim Purwanto. Ilmu Pendidikan Teoritis dan Praktis, Hal. 50

${ }^{6}$ Purwanto, M. Ngalim. 1994. Ilmu Pendidikan Teoritis dan Praktis. (Cet. VII Bandung : Remaja Rosda karya), hal. 59-60 


\section{Empirisme}

Empirisme adalah suatu paham atau aliran yang beranggapan bahwa segala kecakapan dan pengetahuan manusia timbul dari pengalaman (empirik) yang masuk melalui indera. ${ }^{7}$ Menurut penganut aliran ini pengalaman yang diperoleh anak dalam kehidupan sehari-hari terdiri dari stimulant-stimulan alam bebas yang diciptakan olah orang dewasa dalam bentuk program pendidikan. ${ }^{8}$ Jadi menentukan perkembangan anak (manusia) adalah semata-mata faktor eksternal (lingkungan)

John Locke salah seorang tokoh empirsme terkenal dengan teori tabularasnya. Menurut teori ini anak yang baru dilahirkan dapat diumpamakan sebagai kertas putih bersih yang belum ditulisi(a sheet of white peper avoid of all characters). Artinya bahwa anak sejak lahir tidak mempunyai pembawaan apa-apa (netral), tidak punya kencendrunga untuk menjadi baik atau menjadi buruk. Dengan demikian anak dapat dibentuk sekehendak pendidiknya dengan kata lain hanya pendidikan atau lingkungan yang berperan atas pembentukan anak. ${ }^{9}$

Pengaruh aliran ini tampak juga pada salah satu mazhab psikologi yang disebut juga sebagai behaviorisme (aliran tingkah laku). Pada tokoh aliran ini seperti Thorendike, I. Pavlov, J.B Watson dan F.Skinner berpendapat bahwa manusia adalah mahluk yang passif dan dapat dimanipulasi, umpama melalui modifikasi tingkah laku. Mereka memandang manusia sebagai mahluk reaktif (tidak aktif). Manusia hanyalah objek benda hidup yang hanya dapat memberi respon kepada perangsang yang bersal dari lingkungannya. ${ }^{10}$

Dengan demikian empirisme berpandangan bahwa pendidik memegang peranan yang sangat menentukan dalam proses pendidikan. Pendidikanlah yang menyediakan lingkungan pendidikan kepada anak didik dan diterima oleh anak sebagai pengalaman, kemudian dari pengalaman akan terbentuk sususnan kebisaan yang berbentuk pribadi seseorang.

\section{Nativisme}

${ }^{7}$ M. Ngalim Purwanto. Ilmu Pendidikan Teoritis dan Praktis,Hal. 16.

${ }^{8}$ Umar Thirtaharja dan Lasula, Pengantar Pendidikan, (Cet I Jakarta : Rinheka Cipta, 2000) hal. 194

${ }^{9}$ M. Ngalim Purwanto. Ilmu Pendidikan Teoritis dan Praktis, Hal. 15-16

${ }^{10}$ Umar Thirtaharja dan Lasula, Pengantar Pendidikan, hal. 195 
Sebagai reaksi terhadap empirisme, muncul teori nativisme. Istilah natvisme berasal dari kata nativus (latin) yang berarti karena kelahiran. ${ }^{11}$

Aliran nativisme berpendapat bahwa tiap-tiap anak dilahirkan dengan membawa potensi (bawaan) yang akan berkembang sendiri menurut arahnya masing-masing. Bagi nativisme lingkungan sekitar tidak ada artinya, sebab lingkungan tidak akan berdaya dalam mempengaruhi perkembangan anak. Tokoh nativisme Schopenhanuer berpendapat bahwa bayi lahir beserta pembawaannya baik atau buruk. Seorang anak yang mempunyai pembawaan baik, maka dia akan menjadi baik, sebaliknya, kalau anak mempunyai pembawaan buruk, maka dia akan tumbuh menjadi anak yang jahat. Pembawaan itu tidak akan dapat diubah oleh kekuatan luar (lingkungan). ${ }^{12}$

Dengan demikian dapat dipahami bahwa aliran ini dapat dipahami bahwa keberhasilan pendidikan ditentukan oleh hal-hal yang berhubungan dengan internal pada anak didik sendiri. Dengan kata lain hasil ahir pendidikan ditentukan oleh pembawaan yang dibawa sejak lahir. Pendidikan yang tidak sesuai dengan pembawaan atau bakat anak didik tidak akan berguna untuk perkembangan anak tersebut. Oleh karena itu pendidikan sebenarnya tidak diperlukan, dan inilah yang disebut pesimisme paedagogis.

\section{Naturalisme}

Pandangan ini mirip dengan pandangan nativisme dikemukakan oleh para penganut naturalism. Sesuai dengan akar kata naturalism yakni nature "alam" atau apa yang dibawa sejak lahir. Aliran ini berpendapat bahwa seorang anak telah mempunyai pembawaan sejak lahir. ${ }^{13}$

Meskipun kedua aliran ini sepakat dalam hal adanya pembawaan pada manusia, namun J.J Rousseau (tokoh utama naturalisme berbenda pendapat dengan Schopenhauer (nativisme) tentang pembawaan tersebut. Schopenhauer benpendapat bahwa bayi lahir dengan dua kemungkinan yaitu baik atu buruk. Sedangkan Rousseau berpendapat bahwa semua anak yang baru dilahirkan hanya mempunyai pembawaan yang baik. ${ }^{14}$

Kalau dalam hal keberadaan pembawaan manusia pandangan antara nativisme dengan naturalism ada kesamaan, maka dalam hal

\footnotetext{
${ }^{11}$ M. Ngalim Purwanto. Ilmu Pendidikan Teoritis dan Prakti, Hal. 16

${ }^{12}$ Umar Thirtaharja dan Lasula, Pengantar Pendidikan, hal. 196

${ }^{13}$ M. Ngalim Purwanto. Ilmu Pendidikan Teoritis dan Prakti,Hal. 46

${ }^{14}$ Umar Thirtaharja dan Lasula, Pengantar Pendidika, hal. 197
} 
besarnya peranan lingkungan dalam mempengaruhi perkembangan anak, justru pandangn naturalism memiliki kesamaan dengan empirisme. Hal ini dapat dilihat dalam pernyataan J.J Rousseau bahwa semua nak adalah baik pada waktu baru dating dari sang pencipta, tetapi semua rusak ditengah manusia. ${ }^{15}$

Jadi walaupun manusia lahir dengan potensi pembawaan baik, tetapi bagaimana hasil perkembangan kemudian sangat ditentukan oleh pendidikan yang diterimanya atau yang mempengaruhinya. Jika pengaruh itu baik akan menjadi baik, tetapi bilaman pengaruh itu jelek akan jelek pula hasilnya.

Dengan berasumsi pada teori di atas, maka dalam hal pendidikan Rosseau berpendapat bahwa pendidikan yang diberikan orang dewasa malahan dapat merusak pembawaan anak yang baik itu. Karena pendapat inilah, maka naturalism juga sebagai negativism. Mereka berpendapat bahwa pendidi wajib membiarkan pertumbuhan anak pada alam, inilah yang disebut sebagai "pendidikan alam"dengan pendidikan alam anak dibiarkan berkembang menurut alamnya, manusia atau masyarakat jangan mencampurinya, agar pembawaan yang baik itu tidak merusak oleh tangan manusia melalui proses dan kegiatan pendidikan yang dilakukan oleh manusia. ${ }^{16}$

Dengan demikian dapat dipahami bawa naturalism sebagaimana nativisme, tidak menganggap perlu diadakannya pendidikan (oleh manusia) bagi manusia. Bahkan dengan anggapan bahwa pendidikan dapat merusak pembawaan baik anak, naturalism justru dapat dianggap menentang pelaksanaan pendidikan yang dilaksanakan oleh manusia.

\section{Tut Wuri Handayani}

Istilah tut wuri handayani berasal dari bahasa jawa. Tut wuri berarti mengikuti dari belakang dan handayani berarti mendorong, memotifasi atau membangkitkan semangat. ${ }^{17}$

Tut wuri handayani (sekarang sudah menjadi semboyan kemendikbud) pada awalnya merupakan inti salah satu dari "asas 1992" yakni tujuh buah asas dari perguruan taman siswa (didirikan pada tanggal 03 Juli 1922oleh Ki Hajar Dewantoro). Asas pertama perguruan taman siswa mengatakan bahwa setiap orang berhak mengatur dirinya dengan mengingat tertibnya persatuan dalam kehidupan umum. Asas inilah yang

\footnotetext{
${ }^{15}$ M. Ngalim Purwanto. Ilmu Pendidikan Teoritis dan Praktis, Hal. 46

${ }^{16}$ Umar Thirtaharja dan Lasula, Pengantar Pendidikan, hal. 197

17 M. Ngalim Purwanto. Ilmu Pendidikan Teoritis dan Praktis, Hal. 49
} 
mendorong taman siswa untuk mengganti system pendidikan cara lama yang menggunakan perintah, paksaan dengan hukuman dengan system khas taman siswa yang didasarkan pada perkembangan kodrati. Dari asas inipulahlah lahir system Among, dimana guru memperoleh system pamong yaitu sebagai pemimpin yang berdiri dibelakang dengan semboyan tutwuri handayani yaitu tetap mempengaruhi dengan memberi kesempatan kepada anak didik untuk berjalan sendiri, dan tidak terusmenerus dicampuri, diperintah dan dipaksa. Pamong hanya wajib menyingkirkan segala sesuatu yang meringtangi jalannya anak serta dapat bertindak aktif dan mencampuri tingkah laku atau perbuatan anak apabila mereka sendiri tidak menghidarkan diri dari berbagai rintangan atau ancaman keselamatan atau gerak majunya. Jadi ssistem among adalah cara pendidikan yang diapakai dengan maksud diwajibkan pada guru supaya memperhatikan dan mementingkan kodrat-iradat para siswa dengan tidak melupakan segala keadaan yang mengelilingnya. ${ }^{18}$

Dengan menyimak uraian di atas, dapat dipahami bahwa konsep pendidikan Ki hajar Dewantoro ini mengakui adanya bakat, pembawaan, ataupun potensi-potensi pada anak sejak dilahirkan. Potensi-potensi tersebut sangan mempengaruhi lingkungan dalam proses perkembangan anak. Purwanto menyatakan bahwa kalau dibandingkan dengan aliranaliran pendidikan yang berkembang dibarat, tut wuri handayani lebih mirip dengan aliran Konvergensi dari William Stern. Penganut aliran ini berpandangan anak (manusia) ditentukan oleh proses interaksi antara pembawaan anak dengan lingkungan termasuk pendidikan, yang mempengaruhi anak dalam perkembangannya.

\section{Teori Fitrah}

Dalam pandangan islam kemanpuan dasar pembawaan itu mungkin bisa disejajarkan dengan istilah Fitrah. Secara etimologis, kata fitrah (Arab : Fithrah) berati asal kejadian, bawaan sejak lahir, jati diri dan manusiawi. ${ }^{19}$

Dari segi terminology Islam sejumlah interpretasi terhadap kata Fitrah dalam al-Qur'an dan Hadis di kemukakan para ahli. Berkaitan dengan pembahasan ini, H.M Arifin mengemukakan bahwa sejumlah ayat al-Qur'an dan hadis, serta interpretasi ahli ilmu pendidikan islam terhadap keduanya telah memungkinkan lahirnya pandangan-pandangan yang

${ }^{18}$ Umar Thirtaharja dan Lasula, Pengantar Pendidikan, hal. 118-119

${ }^{19}$ M. Quraish Shihab, Lentera Hati ; Kisah dan Hikmah Kehidupan, (Cet. XVII Bandung : Mizan, 1999) hal. 52 
cenderung kepada nativisme, atau konvergensi atau bahkan empiris dalam ilmu pendidikan islam. ${ }^{20}$

Menurut Arifin Fitrah adalah faktor kemampuan dasar perkembangan manusia yang terbawa sejak lahir yang berpusat pada potensi dasar untuk berkembang. Potensi dasar itu berkembang secara menyeluruh (integral) yang menggerakkan seluruh aspek-aspeknya yang secara mekaniktis satu sama lain saling mempengaruhi maju kearah tujuan tertentu. Menurutnya aspek-aspek fitrah terdiri dari komponekomponen dasar (bakat, insting, nafsu, karakter heriditas dan intuisi) yang bersifat dinamis dan responsive terhadap pengaruh lingkungan sekitar, termasuk pengaruh pendidikan.

Adanya pengaruh lingkungan terhadap perkembangan pendidikan anak yang telah lahir membawa fitrah sesuai dengan sabda Rasulullah SAW dalam satu hadis (Albukhari 1997 : 272) yang artinya Setiap bayi dilahirkan dengan fitrah, hanya ibu bapaknyalah (lingkungan) yang menjadikan ia yahudi, nasrani atau majusi.

Dalam konsep islam fitrah dalam hubungannya dengan lingkungan ketika mempengaruhi perkembangan manusia tidak lah netral, sebagaimana pandangan empirisme yang menganggap bahwa bayi yang baru lahir bersih, suci dari pembawaan (potensi) baik atau buruk. Bagi islam bayi lahir dengan membawa suatu fitrah dengan kecendrungan yang bersifat permanen sebagaimana dalam surat ke $30: 30$ yang berbunyi :

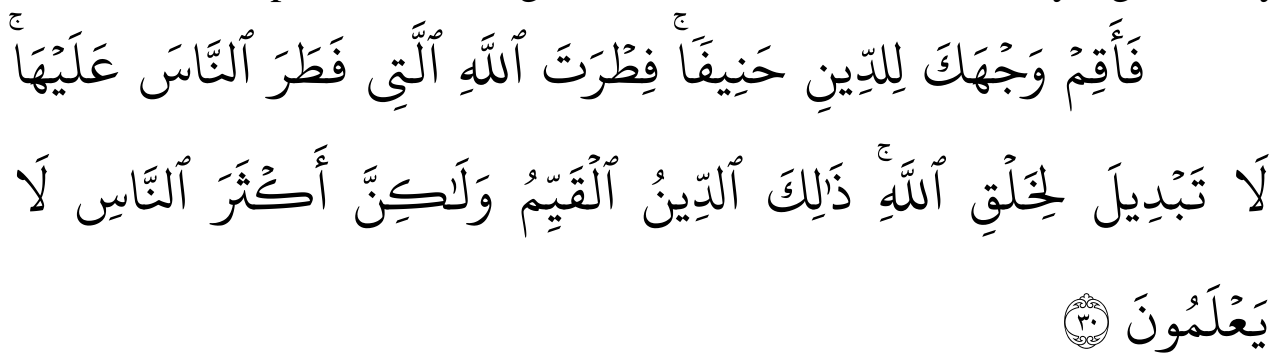

Artinya Maka hadapkanlah wajahmu dengan Lurus kepada agama Allah; (tetaplah atas) fitrah Allah yang telah menciptakan manusia menurut fitrah itu. tidak ada peubahan pada fitrah Allah. (Itulah) agama yang lurus; tetapi kebanyakan manusia tidak mengetahui. ${ }^{21}$

Menurut Hasan Langgulung bahwa fitrah itu dapat lihat dari dua penjuru pertama dari segi pembawaan manusia, yakni potensi

\footnotetext{
${ }^{20}$ H.M Arifin, llmu Pendidikan Islam, (Cet. III Jakarta : Bumi Aksara, 1994) hal 52

${ }^{21}$ Fitrah Allah: Maksudnya ciptaan Allah. manusia diciptakan Allah mempunyai naluri beragama Yaitu agama tauhid. kalau ada manusia tidak beragama tauhid, Maka hal itu tidaklah wajar. mereka tidak beragama tauhid itu hanyalah lantara pengaruh lingkungan.
} 
mengembangkan sifat-sifat tuhan pada dirinya. Kedua fitrah juga dapat dilihat dari segi wahyu Tuhan yang dituturkan kepada nabi-nabinya (agama tahuid : Islam) jadi, potensi manusia dengan agama wahyu adalah suatu "benda" (fitrah) yang dapat diibaratkan mata uang dua sisi. Ini bermakna bahwa agama yang diturunkan melalui wahyu kepada para nabinya adalah sesuai dengan fitrah atau potensi (sifat-sifat) asasi manusia. $^{22}$

Dari apa yang dikemukkan oleh Hasan Langgulung dapat dipahami bahwa fitrah itu berorientasi kepada kebaikan, dengan kata lain manusia itu pada dasarnya adalah baik atau memiliki kencenrungan asasi untek berkembang yang lebih baik. Baik menurut islam yakni bersumber dari Allah Swt bersifat mutlak. Tidak sebagaiman pandangan aliran-aliran sekuler Barat yang erpandangan bahwa baik adalah sesuatu yang bersifat relative dan bersumber pada manusia.

Dalam kaitannya dengan pendidikan meskipun konsep tentang fitrah mirip dengan naturalism yang menganggap bahwa manusia pada dasarnya baik, tetapi islam tidak berpandangan negative dalam pendidikan. Menurut Aburrahman Saleh Abdullah sebagai pendidik muslim selain berihtiar untuk menjauhkan timbulnya pelajaran kebisaaan yang menimbulkan kebisaaan buruk, juga harus berihtiar menanamkan tingkah laku yang baik karena fitrah itu tidak berkembang dengan sendirinya. ${ }^{23}$

\section{Hubungan Pembawaan Manusia Dengan Lingkungan Pendidikan}

Dalam perspektif pendidikan Islam, fitrah manusia dimaknai dengan sejumlah potensi yang menyangkut kekuatan-kekuatan manusia. Kekuatan tersebut meliputi kekuatan hidup, upaya mempertahankan dan melestarikan kehidupannya, kekuatan rasional (akal), dan kekutan spiritual (agama). Ketiga kekuatan ini bersifat dinamis dan terkait secara integral. Potensialitas manusia inilah yang kemudian dikembangkan, diperkaya, dan diaktualisasikan secara nyata dalam perbuatan amaliah manusia sehari-hari, baik secara vertikal maupun horizontal. Perpaduan ketiganya merupakan kesatuan yang utuh.

Dalam pendidikan Islam harus mampu mengintegrasikan seluruh potensi yang dimiliki peserta didiknya pada pola pendidikan yang ditawarkan, baik potensi yang ada pada aspek jasmani maupun rohani, intelektual, emosional, serta moral etis religius dalam diri peserta didiknya. Dengan ini,

${ }^{22}$ Hasan Langgulung, Beberapa Pikiran tentang Pendidikan Islam, (cet II Bandung : AlMa'arif, 1995) Hal 21-22

23 Abdurrahman Saleh Abdullah, Educational Theory a quranic Outlook : diterjemahkan oleh H.M Arifin dan Zainuddin dengan Judul Teori-Teori Pendidikan berdasarkan Al-Qur'an (cet II, Jakarata : Rinheka Cipta, 1994) hal 64 
pendidikan Islam akan mampu membantu peserta didiknya untuk mewujudkan sosok insan paripurna yang mampu melakukan dialektika aktif pada semua potensi yang dimiliknya. Mampu teraktualisasikannya potensi yang dimiliki manusia sesuai dengan nilai-nilai Ilahiyah, pada dasarnya pedidikan berfungsi sebagai media yang menstimuli bagi perkembangan dan pertumbuhan potensi manusia seoptimal mungkin ke arah penyempurnaan dirinya, baik sebagai 'abdillah maupun khalifah.

Fitrah yang dimiliki oleh setiap manusia memiliki kebutuhan. Menurut Zakiyah Drajat ada dua kebutuhan pesertadidik yaitu:

1. Kebutuhan psikis yaitu kebutuhan akan kasih sayang, rasa aman, rasa harga diri, bebas, mengenal, dan rasa sukses

2. Kebutuhan fisik yaitu pemenuhan sandang, pangan, papan, dan pangan

Dalam pendidikan berupaya mengembangkan dan memenuhi kebutuahn tersebut secara integral agar berkembang. ${ }^{24}$

Dalam perkembngannya manusia ingin selalu dipenuhi kebutuhan hidupnya, secara layak dan dapat hidup sejahtera. Tetapi kehidupan sejahtera sifatnya relatif, karena selalu berubah dan berkembang sesuia dengan perkembangan sosial budaya. Semakin maju suatu masyarakat, maka akan semakin beraneka ragam kebutuhannya. ${ }^{25}$

Kebutuhan pokok manusia antara lain yaitu:

\section{Kebutuhan biologis}

Kebutuhan biologis atau kebutuhan jasmaniah, yang merupakan kebutuhan hidup manusia yang primer, seperti makan, tempat tinggal, pakaian, dan kebutuhan sexsual. Setiap orang tentu akan memenuhi kebutuhan biologis tersebut, namun cara pemenuhan kebutuhan tersebut berbeda satu dengan yang lain, tergantung kemampuan dan kebutuhan masing-masing.

\section{Kebutuhan Psikis}

Kebutuhan Psikis yaitu kebutuhan rohaniah. Manusia membutuhkan rasa aman, dicintai dan mencintai, bebas, dihargai, dan lainnya. Manusia adalah makhluk yang disebut "psycho-physik netral" yaitu sebagai makhluk yang memiliki kemandirian jasmaniah dan rohaniah. Dalam kemandirian itu manusia memiliki potensi untuk berkembang dan tumbuh, untuk itu diperlukan adanya pendidikan, agar kebutuhan psikis dapat terpenuhi dengan seimbang.

\footnotetext{
${ }^{24}$ Samsul Nizar, 2001, Pengantar Dasar-Dasar Pemikiran Pendidikan Islam, Gaya Media Pratama: Jakarta, hal: 135-138

${ }^{25}$ Dra. Zuhairini, dkk., 1995, Filsafat Pendidikan Islam, Bumi Aksara : Jakarta. Hal:95- 


\section{Kebutuhan Sosial}

Kebutuhan Sosial, yaitu kebutuhan manusia bergaul dan berinteraksi dengan manusia lain. Karna manusia merupakan makhluk sosial yang memiliki keinginan untuk hidup bermasyarakat. Sebagai makhluk sosial maka manusia memiliki rasa tanggung jawab untuk mengembangkan interaksi antara masyarakat.

4. Kebutuhan Agama (spiritual)

Kebutuhan Agama (spiritual) yaitu kebutuhan manusia terhadap pedoman hidup yang dapat menunjukkan jalan kearah kebahagiaan duniawi dan ukhrawi. Semenjak lahir manusia sudah membawa fitrah beragama dan akan berkembang degan adanya pendidikan. Dengan demikian manusia disebut dengan makhluk berketuhanan atau disebut juga dengan makhluk beragama, karena dengan adanya agama manusia akan dapat ketenangan lahir dan batin.

5. Kebutuhan Paedagogis (intelek)

Kebutuhan Paedagogis (intelek) yaitu kebutuhan manusia terhadap pendidikan. Manusia disebut homo-educandum, yaitu akhluk yang harus dididik, oleh karena manusia itu dikategorikan sebagai animal educable, yakni sebagai makhuk sebangsa binatang yang dapat dididik. Karena manusia mempunyai akal, mempunyai kemampuan untuk berilmu pengeahuan, di samping manusia juga memiliki kemampuan untuk berkembang dan membentuk dirinya sendiri (self-formig).

Dengan demikian jelaslah bahwa manusia dalam hidunya memerlukan pendidikan. Namun pendidikan yang bagaimanakah yang dapat mengembangkan potensi yang ada pada diri manusia yang telah ia bawa semenjak lahir. Karena fitrah manusia pada umumnya sama, hanya saja yang membedakan mereka adalah pendidikan yang mereka dapatkan, sehingga terjadilah beragam agama dan kecerdasan setiap individu.

Ada tiga alasan penyebab awal kenapa manusia memerlukan pendidikan, yaitu:pertama, dalam tatanan kehidupan masyarakat, ada upaya pewarisan nilai kebudayaan antara generasi tua kepada generasi muda, dengan tujuan agar nilai hidup masyarakat tetap berlanjut dan terpelihara. Nilai-nilai tersebut meliputi nilai intelektual, seni, politik, ekonomi, dan sebagainya. Kedua, alam kehidupan manusia sebagai individu, memiliki kecendrungan untuk dapat mengembangkan potensipotensi yang ada dalamdirinyaseoptimal mungkin. Untuk maksud tersebut, manusia perlu suatu sarana. Sarana itu adalah pendidikan. Ketiga, 
konvergensi dari kedua tuntutan di atas yang pengaplikasiannya adalah lewat pendidikan. ${ }^{26}$

Para ahli pendidikan Muslim pada umumnya sependapat bahwa teori dan praktek kependidikan Islam harus didasarkan pada konsepsi dasar tentang manusia. Ada dua implikasi penting dalam hubungannya dengan pendidikan Islam, yaitu. ${ }^{27}$

1. Karena manusia adalah makhluk yang merupakan resultan dari dua komponen (materi dan immateri), maka konsepsi itu menghendaki proses pembinaan yang mengacu kearah realisasi dan pengembangan komponen-komponen tersebut. Sistim pendidikan Islam harus dibangun diatas konsep kesatuan (integrasi) antara pendidikan qalbiyah dan qaliyah sehingga mampu menghasilkan manusia Muslim yang pintar secara intelektual dan terpuji secara moral.

2. Al-quran menjelakan bahwa fungsi penciptaan manusia di alam ini adalah sebagai khalifah dan 'abd. Untuk melaksanakan tugas ini Allah membekali dengan seperagkat potensi. Dalam konteks ini, maka pendidikan harus merupakan upaya yang ditujukan ke arah pengembangan potensi yang dimiliki manusia secara maksimal sehingga dapat diwujudkan dalam bentuk konkrit, dalam arti berkemampuan menciptakan sesuatu yang bermamfaat bagi diri, masyarakat dan lingkungannya sebagai realisasi fungsi dan tujuan penciptaannya, baik sebagai khalifah maupun 'abd.

Kedua hal di atas harus menjadi acuan dasar dalam menciptakan dan mengembangkan sistem pedidikan Islam masa kini dan masa depan. Fungsionalisasi pendidikan Islam dalam mencapai tujuannya sangat bergantung pada sejauh mana kemampuan umat Islam menterjemahkan dan merealisasikan konsep filsafat penciptaan manusia dan fungsi penciptaannya dalam alam semesta ini. Untuk menjawab hal itu, maka pendidikan Islam dijadikan sebagai sarana yang kondusif bagi proses transformasi ilmu pengetahuan dan budaya Islami dari satu generasi ke generasi berikutnya. Dalam konteks ini dipahami bahwa posisi manusia sebagai khalifah dan 'abd menghendaki program pendidikan yang menawarkan sepenuhnya penguasaan ilmu pengetahuan secara totalitas, agar manusia tegar

\footnotetext{
${ }^{26}$ Samsul Nizar, 1999, Peseta Didik Dalam Perspektif Pendidikan Islam: Pengantar Filsafat Pendidikan Islam, IAIN Imam Bonjol Press: Padang, hal: 85

${ }^{27}$ Dr. Al-Rasyidin \& Dr. H. Samsul Nizar, M.A., 2005, Filsafat Pendidikan Islam: Pendekatan Historis, Teoritis dan Praktis, Ciputat Press: Jakarta, hal: 21-23
} 
Dalam buku lain ditemukan bahwa pendidikan merupakan gejala dan kebutuhan manusia. Dalam artian bahwa bilamana anak tidak mendapatkan pendidikan, maka mereka tidak akan menjadi manusia sesungguhnya, dalam artian tidak sempurna hidupnya dan tidak akan dapat memenuhi fungsinya sebagai manusia yang berguna dalam hidup dan kehidupannya. Hanya pendidikanlah yang dapat memnusiakan dan membudayakan manusia. ${ }^{28}$

Untuk mengembangkan potensi/kemampuan dasar, maka manusia membutuhkan adanya bantuan dari orang lain untuk membimbing, mendorong, dan mengarahkan agar berbagai potensi tersebut dapat bertumbuh dan berkembang secara wajar dan secara optimal, sehingga kehidupannya kelak dapat berdaya guna dan berhasil guna. Dengan begitu mereka akan dapat memenuhi kebutuhan hidupnya dan dapat menyesuaikan diri dengan lingkungannya, baik lingkungan fisik maupun lingkungan sosial.

Dari beberapa penjelasan diatas, maka dapat disimpulkan, bahwa fitrah yang dibawa oleh setiap manusia semenjak ia lahir harus dikembangkan dengan pendidikan. Karena sifata manusia yang yang selalu membutuhkan orang lain untuk perubahan dan perbaikan dirinya. Dan juga perkembangan fitrah manusia itu akan di pengaruhi oleh lingkungan. Di dalamfitrah manusia terdapatnya suatu kebutuhan-kebutuhan. Untuk memenuhi kebutuhan tersebut maka perlu adanya bantuan dari orang laian tersebut. Sehingga kebutuhan-kebutuhan tersebut terpenuhi.

\section{Pengaruh Hereditas Dan Lingkungan Terhadap Perkembangan Pendidikan}

1. Pengaruh hereditas terhadap perkembangan Pendidikan anak

Perkembangan adalah serangkaian perubahan yang berlangsung secara terus menerus dan bersifat tetap dari fungsi- fungsi jasmani dan rohani yang dimiliki anak menuju ke tahap kematangan melalui pertumbuhan, pematangan dan belajar.

Manusia dilahirkan dengan struktur jasmani seperti system syaraf, kelenjer dan organ. Semua itu menentukan stabilitas emosi serta membedakan kapasitas mental, maka kesehatan mental dan emosi lebih banyak dipengaruhi oleh hereditas.

2. Pengaruh lingkungan terhadap perkembangan anak

Lingkungan perkembangan anak adalah keseluruhan fonomena (peristiwa, situasi, atau kondisi) fisik atau sosial yang mempengaruhi perkembangan anak.

${ }^{28}$ Zuhairini, dkk., 1995, Filsafat Pendidikan Islam, Hal. 92-95 
a. Keluarga

Keluarga memiliki peranan dalam upaya pengembangan pribadi anak perawatan orang tua yang penuh kasih sayang dan pendidikan tentang nlai- nilai kehidupan, baik agama maupun sosial budaya yang diberikannya merupakan faktor yang kondusif untuk mempersiapkan anak menjadi pribadi dan anggota masyarakat yang sehat.

Pendidikan keluarga itu yang nantinya akan terjungkedalam masyarakat sebagai orang dewasa yang bertanggung jawab atas kehidupan ruma tangganya, dan juga insaf akan kewajibannya sebagai anggota masyarakat

b. Sekolah

Sekolah merupakan lembaga pendidikan formal yang secara sistematis melaksanakan proses bimbingan, pengajaran dan latihan dalam rangka membantu anak agar mampu mengembangkan potensinya, baik yang menyangkut aspek moral-sriritual, intelektual, emosional, maupun sosial.

\section{E. Hubungan Kebebasan dan Ketergantungan Manusia}

1. Paham Kebebasan dalam Islam

Setiap pembahasan mengenai paham kebebasan (free will) dalam teologi islam tidak pernah bisa dipisahkan dari paham qadariyah. Bahkan kaum mu'tazilah yang dalam pemahaman dan sistem teologinya memandang bahwa manusia mempunyai kekuasaan (qudrah) atau yang disebut dengan daya untuk melakukan setiap amalan yang dilakukannya secara penuh. ${ }^{29}$ Sehingga mereka kadangkala dikaitkan dengan qadariah. Lebih jauh lagi kita bisa mengamati berbagai argumentasi dan stetemen yang dikeluarkan oleh pemikir yang berpaham mu'tazilah dalam mempertahankan akidah dan pemahamannya senatiasa memberikan porsi yang lebih besar kepada akal kalau tidak bisa dikatakan hanya mengandalkan nalar.

Aljubbai (seorang tokoh yang berfaham qadariah) menyatakan bahwa manusialah yang menciptakan dan mempunyai wewenang penuh atas setiap amalannya. Baik itu perbuatan yang berupa amal salih maupun yang berupa maksiat. Dan daya untuk mewujudkan setiap tindakannya telah ada dalam diri manusia sebelum perbuatan itu diwujudkan. ${ }^{30}$

\footnotetext{
${ }^{29}$ Harun Nasution, Teologi Islam (Aliran-Aliran Sejarah Analisa Perbandingan), Jakarta: UI Press, 1986, hal.103

30 ibid,
} 
Perbuatan adalah segala sesuatu tindakan yang dilakukan dengan adanya daya melalui berbagai pertimbangan dan dilaksanakan oleh manusia atas dasar pilihan atau kehendaknya (free will) dengan kata lain bukanlah diciptakan oleh Tuhan menurut pandangan mereka.

Dari pembahasan diatas jelas terlihat bahwa kehendak untuk mewujudkan suatu perbuatan adalah kehendak manusia dan atas pilihan manusia sepenuhnya. Lebih lanjut bisa dikatakan bahwa untuk terwujudnya suatu perbuatan yang dilakukan oleh manusia harus didasari oleh adanya daya dan keinginan serta pilihan untuk mewujudkan perbuatan tersebut dan dalam hal ini semua tergantung pada manusia.

Namun lebih jauh dari itu berkaitan dengan hal ini Abdul jabbar, sebagaimana yang dikutib oleh Harun Nasution dalam karyanya dibidang teologi yaitu dalam buku yang berjudul Toelogi Islam Aliran-Aliran Sejarah Analisa Perbandingan menerangkan bahwa Tuhan menciptakan daya dalam diri manusia dan pada daya yang ada pada diri manusia inilah tergantung semua perbuatannya dan bukanlah yang dimaksud disini bahwa Tuhan membuat perbuatan yang telah dibuat oleh manusia. ${ }^{31}$ Secara umum kaum mu'tazilah berpandangan bahwa untuk mewujudkan perbuatan hanya tergantung pada satu daya.

Dengan kata lain problematika kebebasan kehendak menurut aliran Mu'tazilah berkaitan erat dengan prinsip keadilan (Tuhan) yang mereka kembangkan. Mu'tazilah yang berprinsip keadilan Tuhan mengatakan bahwa Tuhan itu adil dan tidak mungkin berbuat zalim dengan memaksa kehendak kepada hamba-Nya kemudian mengharuskan hamba-Nya itu untuk menanggung akibat perbuatannya. Dengan demikian, manusia mempunyai kebebasan untuk melakukan perbuatannya tanpa ada paksaan sedikit pun dari Tuhan. Dengan kebebasan itulah, manusia dapat bertanggung jawab atas segala perbuatannya. Tidaklah adil jika Tuhan memberi pahala atau siksa kepada hamba-Nya tanpa mengiringinya dengan memberikan kebebasan terlebih dahulu. Mereka memandang bahwa keadilan Allah menjadi hilang jika seseorang dituntut harus mempertanggungjawabkan perbuatan yang tidak ia kerjakan, atau jika ia dihisab tentang perbuatan yang tidak ia kehendaki.

Bagi golongan yang berfaham seperti diatas dapat disimpulkan bahwa daya manusialah yang mewujudkan perbuatan dan terbebas dari campurtangan (intervensi) Tuhan. Lebih jauh bisa dikatakan bahwa daya Tuhan tidak mempunyai peranan dalam perwujudan perbuatan-perbuatan

${ }^{31}$ Harun Nasution, Teologi Islam, Hal. 104 
manusia, perbuatan yang dilakukan oleh setiap manusia terwujud hanya karna adanya daya yang diciptakan Tuhan dalam diri manusia.

Untuk mendukung paham diatas kaum qadariah dan juga termasuk mu'tazilah yang berpaham free will mengajukan berbagai alasan-alasan yang didasari pada nalar (rasio) selain itu kaum qadaryah juga mengajukan argumen-argumen yang berupa ayat-ayat Al-Quran yang dapat memperkuat argumentasinya.

Diantara dalil-dalil yang mendukung argumentasi paham ini yaitu Al-Quran surat ar'd ayat 11 yang artinya sebagai berikut : "sesungguhnya Allah tidak akan mengubah nasib suatu kaum, sehingga mereka merobah (nasib) nya sendiri', (Ar-Ra'd : 11)

Selain itu kelompok ini juga mengajukan dalil lainnya yang berupa ayat Al-Quran yaitu yang terdapat dalam surat Al-Kahfi ayat: 29 yang artinya : “...barang siapa yang menghendaki maka berimanlah dan barang siapa yang ingin( kafir) maka kafirlah...(QS. Al-Kahfi: 29)

Menurut faham Qadariyah ayat ini memberikan legitimasi atau kebebasan bagi manusia untuk beriman atau tidak beriman.

Jelaslah menurut paham ini perbuatan manusia merupakan perbuatan yang didasarkan atas kehendak manusia dengan kata lain merupakan perbuatan manusia itu sendiri, baik itu perbuatan yang berupa amal shaleh maupun yang berupa maksiat. ${ }^{32}$

Faham seperti yang dikemukakan diatas dibantah oleh golongan Ahlussunnah yang juga menggunakan dalil Al-Quran untuk mempertahankan argumentasinya, diantara dalil-dalil yang dikemukakan oleh golongan Ahlussunnah yaitu sebagai berikut:

Pertama, Al-Quran surat An-Nisa ayat 78 yang Artinya: "Dan kalau mereka mendapat kebajikan mereka katakan ini dari Tuhan dan kalau mereka mendapat bahaya maka ini dikatakan dari engkau (hai Muhammad). Katakanlah (hai Muhammad): semua dari Tuhan, tetapi kenapa mereka tidak mengerti suatu kejadian"...(QS. An-Nisa: 78)

Selain ayat diatas kaum Ahlussunnah juga mengemukakan dalil lainnya yaitu dalam Al-Quran surat Hud ayat 34 yang Artinya :"Dan tiadalah berguna semua nasehatku kepada kamu kalau aku suka memberi nasehat itu, jika Tuhan hendak menyesatkanmu, Dia-lah Tuhan mu dan kepada-Nya kamu akan dikembalikan" (Qs.Hud ayat: 34)http://www.blogger.com/blogger.g?blogID=5465325234726656158 -_ftn8

Menurut faham Ahlussunnah ayat ini jelas mengindikasikan bahwa setiap orang yang ditakdirkan oleh Tuhan akan sesat maka orang itu tetap

${ }^{32}$ Harun Nasution, Teologi Islam, hal 107 
akan menjadi sesat pada kenyataannya, karena sudah ditakdirkan sejak azali. Dalam ayat lain Allah SWT juga menjelaskan bahwa Dan tidak bisa kamu menghendaki, kecuali jika Tuhan menghendaki (Qs. Al-Insan: 30)

Sehingga bisa difahami disini bahwa menurut pemahaman Ahlussunnah segala tindakan dan amalan yang dilakukan oleh manusia semuanya sudah ditakdirkan dan sudah digariskan sebelum manusia itu melakukan atau mewujudkan perbuatannya bahkan sejak manusia itu belum lahir atau dengan kata lain sudah ditetapkan di azali. Dan juga dapat dipahami bahwa menurut faham Ahlussunnah manusia tak akan mampu berbuat sendiri kalau Tuhan tidak menghendakinya.

2. Paham Ketergantungan dalam Islam

Pembahasan mengenai paham ketergantungan (fatalisme) dalam teologi islam tidak pernah bisa dipisahkan dari paham jabariyah. Dengan istilah lain hal ini juga disebut dengan masalah kehendak muthlak Tuhan. Pembicaraan mengenai hal ini juga sangat erat relasinya dengan pembahasan mengenai kebebasan dan kekuasaan manusia atas segala amalannya. Dalam hal ini seorang tokoh pemikiran islam yang berkebangsaan indonesia yang bernama Harun Nasution, sebagaimana yang dikutib oleh Muhammad Arifin dalam bukunya yang berjudul Teologi Rasional, memandang bahwa, terdapat dua aliran secara garis besar yang mempunyai pandangan yang berbeda dalam hal ini yaitu:

Pertama golongan yang memandang bahwa manusia mempunyai kehendak dan kebebasan atas segala perbuatannya. Dengan kata lain kekuasaan Tuhan tidak lagi bersifat mutlak yang identik dengan pandangan ini adalah golongan mu'tazilah dan qadariyah. Sementara golongan yang kedua yaitu kelompok yang memandang bahwa Tuhan memiliki kekuasaan dan kehendak mutlak atas segala amalan manusia dan segala sesuatu yang terjadi atas dasar kehendak Tuhan, adapun yang diidentikkan dengan pemahaman seperti ini yaitu golongan asy'ariyah dan jabariah. $^{33}$

Lebih lanjut Al-Ghazali sebagai mana yang dikutib oleh Harun Nasution juga mengatakan bahwa Tuhan dapat berbuat apa saja yang dikehendaki-Nya, dapat mewujudkan sesuwatu berdasarkan kehendakNya. Hal ini juga senada dengan yang diungkapkan oleh Al-Bazdawi bahwa Tuhan memang berbuat apasaja yang dikehendaki-Nya dan menentukan segala-galanya berdasarkan kehendak-Nya. ${ }^{34}$

\footnotetext{
${ }^{33}$ Harun Nasution, Teologi Islam, hal 29

${ }^{34}$ Ibid., hal. 120-122
} 
Sementara pendapat yang sangat bersebarangan dikemukankan oleh kaum mu'tazilah dan qadariyah yang memandang bahwa kekuasaan Tuhan tidak lagi berlaku secara mutlak. Golongan ini berpandangan bahwa Tuhan telah membatasi diri-Nya dengan memberikan kebebasan kepada manusia dalam menentukan perbuatan dan kehendaknya sendiri. Lebih lanjut juga dijelaskan bahwa Tuhan telah membatasi diri-Nya dengan sifatnya yang adil, Tuhan tidak lagi berbuat sekehendaknya. Kekuasaan dan kehendak muthlak Tuhan menurut mu'tazilah juga telah dibatasi oleh kewajiban-kewajiban-Nya terhadap manusia dan sunnatullah yang tidak mengalami perubahan. ${ }^{35}$

Secara lebih jelas, aliran Mu'tazilah mengatakan bahwa kekuasaan Tuhan sebenarnya tidak mutlak lagi. Ketidakmutlakan kekuasaan Tuhan itu disebabkan oleh kebebasan yang diberikan Tuhan terhadap manusia serta adanya hukum alam (sunatullah)yang menurut Al-Qur'an tidak pernah berubah. Oleh sebab itu, dalam pandangan Mu'tazilah kekuasaan dan kehendak mutlak Tuhan berlaku dalam jalur hukum-hukum yang tersebar di alam semesta. ${ }^{36}$

Kebebasan manusia, yang memang diberikan Tuhan kepadanya, baru bermakna kalau Tuhan membatasi kekuasaan dan kehendak mutlaknya. Demikian pula keadilan Tuhan, membuat Tuhan sendiri terikat pada norma-norma keadilan yang bila dilanggar membuat Tuhan bersifat tidak adil atau zalim. Dengan demikian, dalam pemahaman Mu'tazilah, Tuhan tidaklah memperlakukan kehendak dan kekuasaan-Nya secara mutlak, tetapi sudah terbatas. Selanjutnya, aliran Mu'tazilah mengatakan, sebagaimana yang dijelaskan oleh Abd Al-Jabbar, bahwa keadilan Tuhan mengandung arti Tuhan tidak berbuat dan tidak memilih yang buruk, tidak melalaikan kewajiban-kewajiban-Nya kepada manusia, dan segala perbuatan-Nya adalah baik. Jalan pikiran ini tidak menghendaki sifat zalim dalam menghukum, memberi beban yang tidak patuh bagi Allah. Dengan kata lain, Tuhan dalam pandangan Mu'tazilah, mempunyai kewajibankewajiban yang ditentukan-Nya sendiri bagi diri-Nya. ${ }^{37}$

Mu'tazilah membagi perbuatan manusia menjadi dua klasifikasi: Ikhtiariah danidtirar. Perbuatan-perbuatan ikhtiariah adalah tindakan-tindakan yang dituju akal manusia dengan berdasarkan pada pengetahuan dan kehendak. Perbuatan-perbuatan jenis ini merupakan

\footnotetext{
${ }^{35}$ Ibid., hal. 29

${ }^{36}$ Rosihon Anwar dan Abdul Rozak, Ilmu Kalam, Bandung: Pustaka Setia, 2003, h.183

${ }^{37}$ Ibid., h. 183
} 
alasan bagi taklif seperti shalat dan puasa. Sedangkan perbuatanperbuatanidtidar adalah perbuatan-perbuatan yang terjadi dengan sendirinya, tanpa ada campur tangan dari kehendak manusia, seperti api membakar dan menggigil ketika dingin. Pengaitan perbuatan itu kepada manusia kadang-kadang secara allegoris (majaz) karena perbuatan itu terjadi di tangannya. Perbuatan adalah sesuatu yang temporal, sehingga harus ada yang menciptakan. Mu'tazilah serius mengkaji masalah ini, khususnya tentang pencipta bagi perbuatan-perbuatan ikhtiariah.

\section{KESIMPULAN}

Dari uraian diatas dapat disimpulkan hal-hal sebagai berikut :

1. Heriditas adalah istilah yang dipakai untuk menyebut semua potensi yang dibawa sejak lahir dan memiliki kemungkinan untuk muncul pada perkembangan manusia. Istilah ini mencakup pengertian bakat dan keturunan. Adapun lingkungan adalah sesuatu yang mempengaruhi perkembangan diri manusia

2. Mengenai implikasi heriditas dan lingkungan dalam perkembangan diri manusia telah muncul berbagai pandangan yang beragam baik dibarat maupun di dunia Islam. Dibarat muncul aliran empirisme bahwa lingkungan berpengaruh mutlak terhadap perkembangan manusia, nativisme berpandangan bahwa perkembangan manusia mutlak ditentukan oleh pembawaannya. Naturalism berpandangan bahwa pada dasarnya manusia adalah baik dan kebaikan ini akan bertahan jika dalam perekebangannya tumbuh secara alami (tanpa pengaruh rekayasa manusia) konvergensi kalau diindonesia diwakili oleh tut wuri hanadayani merupakan aliran yang memadukan antara empirisme dengan nativisme yang berpandangan bahwa perkembangan manusia ditentukan oleh interaksi antara pembawaan dengan lingkungan.

3. Dalam mengkaji masalah kebasan manusia dan ketergantungan pada Tuhan dalam ranah teologi islam kita bisa menemukan adanya perbedaan pandangan dari aliran-aliran yang ada dalam teologi islam, masing-masinga aliran mempunyai pemahaman yang berbeda berdasarkan argumen-argumen masing-masing. Kaum mu'tazilah yang dalam pemahaman dan sistem teologinya memandang bahwa manusia mempunyai kekuasaan (qudrah) atau yang disebut dengan daya untuk melakukan setiap amalan yang dilakukannya secara penuh, artinya daya manusialah yang mewujudkan perbuatan dan terbebas dari campur tangan (intervensi) Allah, karena Allah telah memberikan kekuasaan kepada manusia. Sementara menurut pemahaman Asy'ariyah segala tindakan dan amalan yang dilakukan oleh manusia semuanya sudah ditakdirkan dan sudah digariskan oleh Tuhan sebelum 
manusia itu melakukan atau mewujudkan perbuatannya bahkan sejak manusia itu belum lahir atau dengan kata lain sudah ditetapkan di azali. Dalam memahami masalah kekuasaan Tuhan ada dua golongan secara garis besar yaitu Pertama golongan yang memandang bahwa manusia mempunyai kehendak dan kebebasan atas segala perbuatannya. Dengan kata lain kekuasaan Tuhan tidak lagi bersifat muthlak yang identik dengan pandangan ini adalah golongan mu'tazilah dan qadariyah. Sementara golongan yang kedua yaitu kelompok yang memandang bahwa Tuhan memiliki kekuasaan dan kehendak muthlak atas segala amalan manusia dan segala sesuatu yang terjadi atas dasar kehendak Tuhan, adapun yang diidentikkan dengan pemahaman seperti ini yaitu golongan asy'ariyah dan jabariah.

\section{DAFTAR PUSTAKA}

Abdullah, Abdurrahman Saleh.1994. Educational Theory a quranic Outlook : diterjemahkan oleh H.M Arifin dan Zainuddin dengan Judul Teori-Teori Pendidikan berdasarkan Al-Qur'an. cet II, Jakarata : Rinheka Cipta.

Anwar, Rosihon dan Abdul Razak. 2003. Ilmu Kalam. Bandung : Pustaka Setia

Arifin, H.M. 1994. llmu Pendidikan Islam. Cet. III Jakarta : Bumi Aksara.

Langgulung, Hasan. 1995. Beberapa Pikiran tentang Pendidikan Islam. cet II Bandung : Al-Ma'arif.

Mohamed, Yasien. 1997. Insan Yang Suci : Konsep fitrah dalam Islam. Bandung : Mizan

Nasution, Harun. 1986. Teologi Islam; Aliran-Aliran Sejarah Analisa Perbandingan. Jakarta : UI Press.

Nizar, Samsul. 2001. Pengantar Dasar-Dasar Pemikiran Pendidikan Islam. Gaya Media Pratama: Jakarta.

, 1999. Peseta Didik Dalam Perspektif Pendidikan Islam: Pengantar Filsafat Pendidikan Islam, IAIN Imam Bonjol Press: Padang

Purwanto , M. Ngalim. 1994. Ilmu Pendidikan Teoritis dan Praktis. Cet. VII Bandung : Remaja Rosda karya

Rasyidin, al\& Samsul Nizar. 2005. Filsafat Pendidikan Islam: Pendekatan Historis, Teoritis dan Praktis. Ciputat Press: Jakarta 
Shihab, M. Quraish1999. Lentera Hati ; Kisah dan Hikmah Kehidupan. Cet. XVII Bandung : Mizan

Thirtaharja ,Umar dan Lasula. 2000. Pengantar Pendidikan. Cet I Jakarta : Rinheka Cipta.

Tim Penyusun kamus pusat pembinaan dan pengembangan bahasa. cet. II Jakarta : Balai Pustaka.1989

Zuhairini, dkk. 1995. Filsafat Pendidikan Islam. Jakarta : Bumi Aksara 